\title{
SISTEM EKONOMI HUMANISTIK VERSUS EKONOMI BEBAS
}

\author{
Atmo Prawiro ${ }^{凶}$ \\ Universitas Islam Negeri Syarif Hidayatullah Jakarta
}

\begin{abstract}
Abstrak
Perdebatan sistem ekonomi dunia yang dimulai pasca perang dingin hingga saat ini dapat dikatakan kemenangan ada pada sistem kapitalistik yang menggunakan pasar bebas sebagai salah satu cirinya. Runtuhnya Unisovyet menandakan kekuatan ekonomi kapitalistik sebagai penguasa ekonomi dunia. Karena hampir semua negara di dunia menerapkan sistem ini. Di beberapa negara dunia sebenarnya banyak sekali sistem ekonomi yang digunakan, namun faktanya sebagian besar dunia kapitalistik yang mendominasinya. Demikian pula Indonesia yang menganut sistem kapitalis pasar bebas, meskipun dalam konstitusinya Indonesia menggunakan ekonomi pancasila (ekonomi humanistik) yang mencintai kebersamaan (ukhwah) dan ruh keagamaan. Penelitian ini menggunakan pendekatan deskriptif analisis, dengan sumber yang digunakan adalah buku-buku terbitan dan jurnal.

Penulis menemukan bahwa sistem ekonomi humanis dalam pengertian konsep di atas termasuk kesamaan nilai-nilai Islam, bahkan ekonomi humanis ini memberikan semangat gotong royong, gotong royong dan dimensi spiritual yang tinggi, dan ini sangat berbeda dengan ekonomi pasar bebas yang dikembangkan oleh dunia global. sistem ekonomi kapitalis. Sistem ekonomi pasar bebas ini cenderung menjadi objek manusia, sehingga ada jurang pemisah yang sangat jauh antara masyarakat dengan para konglomerat, dan inilah ciri dari ekonomi pasar bebas. Namun di satu sisi ekonomi humanis memang mengadopsi beberapa sistem kapitalis, serta kepemilikan individu dan juga mengadopsi sosialisme ekonomi dalam hal kebersamaan.
\end{abstract}

Kata Kunci: ekonomi humanistik, ekonomi kapitalis, dan ekonomi pancasila 
DOI: https://doi.org/10.55252/annawawi.v1i1.8

\begin{abstract}
The debate of the world economic system that began post-cold war until today can be said victory is in the capitalistic system that uses the free market as one of its characteristics. The collapse of Unisovyet signifies the power of capitalistic economy as the ruler of the world economy. Because almost the countries in the world apply this system. In some countries the world is actually a lot of economic system that is used, but the fact that most of the capitalistic world that dominate it. Similarly, Indonesia is also a free market capitalistic system, although Indonesia in its constitution uses Pancasila economy (humanistic economy) which loves togetherness (ukhwah) and religious ruhs. This research uses descriptive analysis approach, with the sources used are published books and journals.

The author finds that the humanist economic system in terms of the above concept belongs to the commonalities of Islamic values, even this humanist economy provides for mutuality, mutual help and high spiritual dimension, and this differs greatly from the free market economy developed by the global capitalist economic system. This free market economic system tends to be the object of human being, so there is a very far gap between the community and the conglomerates, and this is the hallmark of the free market economy. But on the one hand the humanist economy does adopt some capitalist system, as well as individual ownership and also adopt the economic socialism in terms of togetherness.
\end{abstract}

Keywords: humanistic economy, capitalistic economy and Pancasila economy 
Copyright (c) 2021 Atmo Prawiro

$\triangle$ Corresponding author: Atmo Prawiro

Email Address : atmo.prawiro@uinjkt.ac.id

\section{PENDAHULUAN}

Tulisan ini jika mengikuti alur tema, maka meniscayakan pemahaman akan adanya pertentangan model ekonomi yang kita anut dalam konstitusi kita, yaitu antara Ekonomi Humanistik (ekonomi pancasila) versus Ekonomi Pasar Bebas. Pembagian inipun, sepanjang pengetahuan penulis, berarti bisa ditafsirkan dengan menafikan ghalib-nya main stream ekonomi lainnya, dengan menambahkan satu paradigma baru, yaitu komunisme atau lebih aman disebut sosialisme.

${ }^{1}$ Kegagalan akan suatu bangsa dalam mengelola negara lebih banyak disebabkan oleh minimnya kesadaran terhadap sejarah perjalanan bangsanya sendiri. Bahkan seringkali suatu bangsa kehilangan identitas, identitas bangsa Indonesia misalnya sering sekali kehilangan idiologinya sebagai suatau bangsa yang majemuk terutama dalam idiologi (pancasilanya) dikarenakan kurang memahami aturan dasar yang terdapat dalam UUD 1945. Padahal idiologi bangsa memiliki kekutan dalam ketahanan suatu negara. Ketahanan bangsa dipengaruhi oleh beberapa faktor, sebut saja faktor ketahanan, faktor karakteristik masyaraktanya dan faktor ekonominya (kesejahtraannya). Makalah ini akan menguraikan pertentangaan yang taajam antara sistem konstitusi ekonomi Indonesia dengan ekonomi pasar bebas.

Sitem perekonomian di dunia dewasa ini cenderung kepada sistem Ekonomi liberal-kapitalistik. Pasca runtuhnya Unisovyet sebagai wakil daripada sistem ekonomi sosialis,kini sistem kapitalistik cenderung menguasai dunia, bahkan menggurita hampir disemua negara-negara di dunia. Pertarungan dua sistem itu yang pada akhirnya dimenangkan oleh sistem ekonomi kapitalistik tela merambah ke negaranegara berkembang, bahkan Cina yang dikenal wakil dari ekonomi sosialis, kini Cina pun sudah mengadopsi sistem ekonomi kapitaslitik, dan pada akhirnya hanya ada satu sitem ekonomi didunia ini yang mendominasi. Padahal sitem ini digerakkan oleh para homo-economicus, yaitu makhluk ekonomi rakus yang insting dan perilakunya mencari kepuasan dan keuntungan maksimal. Mereka menjadi ahli dalam hal meminimumkan biaya dan memaksimalkan perolehan. ${ }^{2}$

Indonesi sebagai negara yang berkembang bagian dari objek dari menyebarnya ekonomi global, kita bisa melihat fakta dilapangan menunjukan penggunaan ekonomi kapitalistik dengan sistem pasar bebasmenguasai ekonomi nasional. Sebagai Negara yang berkembang maka tidak heran pula Indonesia menerapkan liberalkapitalistik tersebut, padahal Indonesia sendiri didalam konstitusinya bukanlah menganut sistem ekonomi pasar bebas yang selama ini hampir dipraktekan oleh masyarak Indonesia, akan tetapi sistem ekonomi yang dianut adalah sistem ekonomi kerakyatan (sistem ekonomi humanistik) yang berdasarkana atas asas kekeluargaan, sebagaimana yang tercantum dalam UUD 1945, hal ini dikemukakan dalam Pasal 33 UUD 1945, adalah

${ }^{1}$ Dikotomi paradigma ekonomi cendekiawan lebih banyak membandingkan antara Kapitalisme dengan Sosialisme. Lihat Anthony Gidden, Kapitalisme dan Teori Sosial Modern, Suatu Analisis terhadap Karya Tulis Mark, Durkheim dan Max Weber (Jakarta: UI- Press, 1986); Winardi, Kapitalisme Versus Sosialisme (Bandung: Remadja Karya, 1986). Adi Sasono, Didin Hafiduddin dan AM. Saepuddin dkk membagi tiga paradigma system ekonomi dunia. lihat Adi Sasono dkk, Solusi Islam Atas Problematika Umat: Ekonomi, Pendidikan, dan Dakwah (Jakarta: GIP, 1998); Anwar Abbas, Bung Hatta dan Ekonomi Islam: Menangkap Makna Maqāshid al-Syarī'ah (Jakarta: Kompas Media Nusantara, 2010).

2Sri Edi Swasono, “Koperasi: Koperasi dan Ekonomi Humanistik,” diakses 30 November 2017, / koperasi-dan-ekonomi-humanistik.html. 
sebuah sistem perekonomian yang ditujukan untuk mewujudkan kedaulatan rakyat dalam bidang ekonomi. Tiga prinsip dasar ekonomi kerakyatan adalah sebagai berikut: (1) perekonomian disusun sebagai usaha bersama berdasar atas azas kekeluargaan; (2) cabang-cabang produksi yang penting bagi negara dan yang menguasai hajat hidup orang banyak dikuasai oleh negara; dan (3) bumi, dan air, dan segala kekayaan yang terkandung didalamnya dikuasai oleh negara dan dipergunakan bagi sebesar-besarnya kemakmuran rakyat.

Perekonomian nasional yang melandaskan asasnya atas asas kebersamaan (ukhwah) seperti konstitusi ekonomi kita diatas nampaknya jika dihadapkan dengan perekonomian global yang penuh dengan kebebasan, mampukah perekonomian kita ikut serta dalam kancah perekonomian negerinya sendiri sebagai subjek bukan lagi objek yang selama ini terjadi?

\section{SISTEM EKONOMI HUMANISTIK}

Membincang sistem ekonomi humanistik, maka kita akan membincang tentang humanisme Pancasila, hal ini didasarkan pada kajian Prof. Soerjanto Poespowardojo, dan Prof. Franz Magnis-Suseno. bahwa Pancasila sebagai ideologi negara menyatakan kelima sila, yaitu Ketuhanan Yang Maha Esa, Kemanusiaan yang adil dan beradab, Persatuan Indonesia, Kerakyatan yang dipimpin oleh hikmah kebijaksanaan dalam permusyawaratan/ perwakilan, dan Keadilan Sosial bagi seluruh rakyat Indonesia, merupakan prinsip dasar serta pedoman bagi bangsa Indonesia dan hidup kenegaraannya. memahaami kepadatan substansi tersebut, sewajarnya kita lakukan kekayaan yang terkandung di dalamnya dandicoba memahaminya dengan mengungkapkan nilai-nilai serta hubungan antarnilai dan antarsila dalam bentukbentuk yang lebih eksplisit. ${ }^{3}$

Suatu rumusan hanya dapat dipahami dengan memperlihatkan fungsinya apabila dikaitkan dengan jalan serta alam pikiran pelaku (pengemban) yang merumuskannya dan lebih-lebih kalau dikaitkan dengan penghayatan eksistensial, dimana rumusan tersebut merupakan motif dasar berbagai bentuk tindakannya. Secara fenomenologis dapat dikatakan bahwa kelima sila itu berlaku bagi manusia. ${ }^{4}$ Pada dasarnya tidak seorang pun dapat dilepaskan dari kelima sila tersebut tanpa risiko menyalahi kemanusiaannya, meskipun berdasarkan kemerdekaan yang dimilikinya sebagai hak asasi ia mampu berbuat berlawanan dengan sila-sila itu, namun secara etis tetap terikat untuk menaatinya. Kesadaran akan kenyataan ini dengan sendirinya mengaitkan kelima sila sebagai keseluruhan nilai dengan kodrat manusia, maka disebut Humanisme Pancasila. ${ }^{5}$

Bagi penulis dalam hal ini bahwa manusia menurut Pancasila adalah manusia yang memanusiakan dirinya dalam hubungannya dengan ketiga faktor esensial, yaitu dunia (materi), sesama (masyarakat) dan prinsip ketuhanan (agama). Begitupula apa yang dimaksud ekonomi humanistik dalam pandangan penulis adalah ekonomi yang memanusiakan manusia, ekonomi yang bisa berdampingan dengan materi tanpa megexploitasi, masyarakat banyak tanpa mendzalimi satu dengan yang lainnya dan ekonomi yang memiliki nilai-nilai ketuhanan. Ketiga ciri diatas hanya bisa dilakukan oleh manusia, karena manusia adalah mahluk sosial, mahluk yang bretika dan juga mahluk berketuhanan. Sri Edi menjelaskan homo-socius (mahluk sosial) adalah

3Poespowardojo, Soerjanto. "Filsafat Pancasila (Sebuah Pendekatan Sosio Budaya) Gramedia." (1989). 54; baca juga Mustansyir, R. (1995). Bhinneka Tunggal Ika, Dalam perspektif filsafat analitik. Jurnal Filsafat, (1995).

4Pranarka, A. M. W. (1985). Sejarah pemikiran tentang Pancasila. Yayasan Proklamasi, Centre for Strategic and International Studies.

${ }^{5}$ Kuswanjono, Arqom. "Pluralisme Pancasila." Jurnal Filsafat 16.1 (2016): 77-93. 
makhluk sosial yang menjaga kerukunan antarsesama dan bekerja sama untuk kepentingan bersama. Homo-socius cenderung menjadi homo-ethicus, homo-religious, sekaligus homo-humanus, ${ }^{6}$ yang mengemban etika dan moralitas rukun agawé santosa, saling solider bekerja sama tolong- menolong, dalam kearifan lokal paro-édhing atau sithik-édhing, bukan yang saling bersaing, bermuslihat, dan bertarung menangmenangan sebagaimana homo-economicus.

Manusia pada dasarnya juga menganut paham kolektivisme (communitarianisme), yang menurut Edi Swasono dalam bahasanya Irwansyah mahluk sosial memiliki paham kebersamaan (mutualisme) dan kekeluargaan (brotherhood), berikut kepentingan bersama (mutual interest) yang menyertainya, ditempatkan pada kedudukan utama. Anggota-anggota masyarakat berada di bawah lindungan masyarakat sebagai makhluk sosial (homo-socius). Membincang ekonomi humanis pada dasarnya membahas ekonomi yang kolektivitas, brotherhood, dan relgious.

Ketiga prinsip diatas pelaku utamanya adalah manusia, bukan materi yang seperti halnya kapitalisme. Masyarakat dalam hal ini memiliki posisi substansial, bukan menempatkannya pada posisi residual atau marginal. Hal ini sepaham dengan ekonomi pancasila yang tertuang dalam Pasal 33 UUD 1945 “.. dalam demokrasi ekonomi kemakmuran masyarakatlah yang diutamakan, bukan kemakmuran orangseorang..". Namun demikian, hak-hak individu dan martabat individu dalam ekonomi pancasila tetap diakui dan dijunjung tinggi. ${ }^{7}$

Dalam posisi ekonomi humanis maka ada beberapa hal yang harus dihindari yaitu:

1. Sistem free fight liberalism yang menumbuhkan eksploitasi terhadap manusia dan bangsa lain yang dalam sejarahnya di Indonesia telah menimbulkan dan mempertahankan kelemahan struktural ekonomi nasional dan posisi Indonesia dalam perekonomian dunia. Dalam sistem ekonomi kapitalis berlaku "Free Fight Liberalism" (sistem persaingan bebas) ${ }^{8}$. Siapa yang memiliki dan mampu menggunakan kekuatan modal (Capital) secara efektif, efisien dan rpoduktif akan memenangkan pertarungan dalam bisnis. ${ }^{9}$ Paham yang mengagungkan kekuatan modal sebagai syarat untuk memenangkan pertarungan ekonomi disebut sebagai Capitalisme. Ekonomi konvensional di bawah dominasi kapitalisme saat ini sedang menghadapi masa krisis dan re-evaluasi. Sebagaimana disebut di atas, kapitalisme menghadapi kritikan dari berbagai penjuru. Mulai dari Karl Max ${ }^{10}$ sampai

${ }^{6}$ Giustiniani, V. R. (1985). Homo, humanus, and the meanings of'humanism'. Journal of the History of Ideas, 167-195. Baca juga INDONESIA, P. R., \& Indonesia, P. R. (1984). Undang Undang No. 5 Tahun 1984 Tentang: Perindustrian.

${ }^{7}$ Ilham Firmansyah, "Konsep Ekonomi Pancasila Dan Ekonomi Islam (Analisis Pemikiran Ekonomi Sri-Edi Swasono)," 39, diakses 29 September 2017, https://jurnalsyariahdotcom.files.wordpress.com/2014/06/6-jurnal-ilham-2014.pdf.

${ }^{8}$ Soesastro, M. Hadi. "The political economy of deregulation in Indonesia." Asian Survey 29.9 (1989): 853-869; baca Doyle, Michael W. "Liberalism and world politics." American political science review 80.4 (1986): 1151-1169.

${ }^{9}$ Zubadi, Hamron. "Perlunya Pengenalan Pendidikan Sistem Ekonomi Islam dengan Sistem Ekonomi yang Lain Sejak Dini." Jurnal Fakultas Ekonomi 1.3 (2013).

${ }^{10}$ Kecenderungan Marx untuk menganalisis idea-idea tentang teori kelas ditonjolkan dalam fasal terakhir karyanya iaitu Capital (jilid ketiga). Namun begitu, kematiannya pada tahun 1883 telah mengganggu proses penerbitan karya tersebut. Secara umumnya, konsep kelas sosial yang diutarakan oleh Marx telah diterjemahkan dalam versi sistem ekonomi Kapitalisme. 
pada era tahun 1940-an,1950-an, 1960an, bahkan di awal abad 21 kritikan tersebut semakin tajam dan meluas. seperti Joseph Schumpeter, Daniel Bell, Irving Kristol, Gunnar Myrdal, Paul Omerod, Umar Ibrahim Vadillo, Critovan Buarque, sampai kepada Joseph Stigliz. ${ }^{11}$ Banyak indikasi kegagalan kapitalisme, karena: pertama, Ekonomi konvensional yang berlandaskan pada sistem ribawi, ternyata semakin menciptakan ketimpangan pendapatan yang hebat dan ketidak-adilan ekonomi. Kedua, Ekonomi kapitalisme juga telah menciptakan krisis moneter dan ekonomi di banyak negara. Di bawah sistem kapitalisme, krisis demi krisi terjadi terus menerus, sejak tahun 1923, 1930, 1940, 1970, 1980, 1990, 1997 bahkan hingga saat ini. Banyak negara senantiasa terancam krisis susulan di masa depan jika sistem kapitalisme terus dipertahankan. Ketiga, Ekonomi kapitalisme banyak melakukan kesalahan dalam sejumlah premisnya, terutama rasionalitas ekonomi yang telah mengabaikan moral dimensi moral. ${ }^{12}$

2. Sistem etatisme dalam arti bahwa negara berserta aparatus ekonomi negara bersifat dominan, mendesak dan mematikan potensi serta daya kreasi unitunit ekonomi diluar sektor negara. dimana ekonomi dikuasai oleh negara karena etatisme dapat mematikan usaha-usaha di luar sektor negara seperti usaha swasta, koperasi, dan usaha kecil.13

Sistem ini memiliki ciri-ciri sebagai berikut. a. Semua alat dan sumbersumber daya dikuasai pemerintah. b. Hak milik perorangan tidak diakui. c. Tidak ada individu atau kelompok yang dapat berusaha dengan bebas dalam kegiatan perekonomian. d. Kebijakan perekonomian diatur sepenuhnya oleh pemerintah. Tentunya hal ini akan mematikan inisiatif individu untuk maju, sering terjadi monopoli yang merugikan masyarakat, dan masyarakat tidak memiliki kebebasan dalam memilih sumber daya. ${ }^{14}$

3. Persaingan tidak sehat serta pemusatan kekuatan ekonomi pada satu kelompok dalam berbagai bentuk monopoli dan monopsoni yang merugikan masyarakat dan cita-cita keadilan sosial.dalam kenyataan dilapangan hampirtidak pernah ditemui suatu pasar di manaterdapat persaingan sempurna. Yang seringterjadi adalah persaingan tidak sempurna.Kendati demikian, persaingan tetapdipandang sebagai sesuatu yang esensialdalam ekonomi pasar. Persaingan tetapdiakui hanya saja asumsi-asumsi yangmendasarinya tidak sama dengan asumsi-aumsi yang mendasari

Dalam karya tersebut, Marx telah membahagikan tiga kelas utama dalam struktur masyarakat kapitalis iaitu kelas buruh upahan (Wage Labourers), kelas kapitalis dan kelas pemilik tanah (Landowner), tetapi struktur tersebut masih belum kukuh walaupun wujud usaha kelas pertengahan untuk menghapuskan jurang pemisah antara kelas-kelas tersebut.Marx, K., Capital. Jil 1. Moscow: Progress ublisher, (1959): 504; bacaIsmail, Indriaty, dan Mohd Zuhaili Kamal Basir. "Karl Marx dan Konsep Perjuangan Kelas Sosial." International Journal of Islamic Thought 1 (2012): 27.

11 Stiglitz. Joseph. Freefall: America, Free Market and The Sinking of Global Economy (New York: Norton Company, 2009).

12 Ismail, Indriaty, dan Mohd Zuhaili Kamal Basir.

13 Abbas, Tarmizi, and Win Konadi Manan. "Keterkaitan antara Demokrasi Politik, Demokrasi Ekonomi dan Sistem Ekonomi Kerakyatan." Mimbar: Jurnal Sosial dan Pembangunan 21.3 (2005): 429-439.

14 Suroso. Perekonomian Indonesia. Jakarta: PT. Gramedia Pustaka Utama, 1994. 
persaingan sempurna. Dalam persaingan yang tidak sempurna inilah akan ditemui praktek-praktek monopolistic dan oligopoly. Peraktek-peraktek monopolistic inilah yang lebih popular disebut sebagai persaingan tidak sehat..$^{15}$ Di dalam Undang-undang No 5/1999, Persaingan Usaha Tidak Sehat adalah "persaingan antar pelaku usaha dalam mejalankan kegiatan produksi dan atau usaha pemasaran barang dan atau jasa yang dilakukan dengan cara tidak jujur atau melawan hukum atau menghambat persaingan usaha. ${ }^{16}$

Dari kelemahan-kelemahan yang dipaparkan diatas Sri-Edi Swasono menjelaskan pentingnya moralitas agama dalam menggambarkan Sistem Ekonomi humanis yaitu ekonomi Pancasila sebagai sistem ekonomi yang berorientasi (atau berwawasan) pada sila-sila Pancasila, yaitu berorientasi kepada 1. Ketuhanan Yang Maha Esa (adanya atau berlakunya etik dan moral agama, bukan materialisme); 2. Kemanusiaan yang adil dan beradab (tidak mengenal pemerasan antar sesama, pengisapan ataupu riba, dan subordinasi ekonomi - modern); 3. Persatuan (kebersamaan, kekeluargaan, gotong-royong, tidak saling mematikan - nasionalisme); 4. Kerakyatan (demokrasi ekonomi, kedaulatan ekonomi, mengutamakan ekonomi rakyat, mengutamakan hajat hidup orang banyak); 5. Keadilan sosial (persamaan, pemerataan, kemakmuran rakyat yang utama bukan kemakmuran orang-seorang). ${ }^{17}$ Mengacu pada rumusan Ekonomi Pancasila Sri-Edi Swasono, maka dapat dikemukakan bahwa pilar Sistem Ekonomi Pancasila tersebut meliputi ekonomika etik dan ekonomika humanistik (dasar), nasionalisme ekonomi dan demokrasi ekonomi (cara/metode operasionalisasi), dan ekonomi berkeadilan sosial (tujuan). Makna "ekonomi pancasila" tersebut adalah suatu perekonomian yang orientasinya pada keterlibatan orang banyak dalam aktivitas ekonomi, dengan mengacu pada nilai-nilai konstitusi dan falsafah bangsa, yakni Pancasila.

Koperasi sebagai bagian dari kooperativisme menolak persaingan bebas meskipun menganjurkan "berlomba" (ber-concours, ber-contest), yang tertinggal ditolong agar maju.

Dalam pemaparan diatas dalam ekonomi kita dikenal paham kompetitivisme (competition-based) dan paham kooperativisme (cooperation-based). Nalar kompetitivisme adalah bersaing untuk mencapai efisiensi ekonomi, dasar ideologinya kebebasan pribadi (individual liberty). Persaingan mendorong kerja keras. Yang bertahan hidup yang kuat, yang lemah tersingkir. Sedangkan nalar kooperativisme adalah bekerja sama membentuk kekuatan lipat ganda bersinergi. Sendiri-sendiri orang tak akan mampu mengangkut benda berat, kerja sama dua orang bisa mengangkat berpuluh kali benda berat. Inilah cooperation-based economy, membentuk sinergi untuk mencapai efisiensi.

Banyak ketidakpahaman soal sistem ekonomi Indonesia. Ada yang mencaricari, ada yang ambivalen, lalu secara keliru menganggap sebagai sistem "jalan tengah" (tulisan saya, Kompas 16/8/2005). UUD kita Pasal 33 Ayat 1 merumuskan

15 Dalam peraktek monopoli, maka besar kemungkinan bahwa produser akan bertindaktidak efisien dan meningkatkan hambatan masuk pasar (barrier to entry) bagi pesaingnya. Bila hal ini terjadi maka efeknya adalah penggunaan sumber daya yang tidak efektif dan membuat pasar menjadi terdistorsi. Lihat, NingrumNatasya Sirait, "Menjual Rugi (Predatory Pricing) Dalam Hukum Persaingan dan pengaturannya dalam undang-undang no 5/1999 dalam jurnal hukum bisnis vo. 1, No. 23. 2004: 71

16 Tarigan, Azhari Akmal. "Peraktek Monopoli Dan Persaingan USAha Tidak Sehat Dalam Perspektif Hukum Ekonomi Dan Hukum Islam." JURNAL MERCATORIA 9.1 (2017): 5463.

${ }^{17}$ Ilham Firmansyah, "Konsep Ekonomi Pancasila Dan Ekonomi Islam (Analisis Pemikiran Ekonomi Sri-Edi Swasono)." 
"Perekonomian disusun sebagai usaha bersama atas asas kekeluargaan" tak lain karena paham ekonomi nasional kita mengutamakan kooperativisme. Lebih dari itu ditegaskan dalam penjelasan Pasal 33: "...bangun perusahaan yang sesuai adalah koperasi...". UUD 2002 (amandemen) tak memiliki penjelasan, tetapi untuk pasal atau ayat-ayat UUD 1945 (asli) yang tak diamandemen, penjelasan tetap berlaku dan dibenarkan Prof Maria Farida (kini anggota Majelis Hakim Mahkamah Konstitusi). Berarti kata "koperasi" tak hilang.

Perkataan "perekonomian", sebagaimana bunyi Ayat (1) Pasal 33 UUD 1945, tentu meliputi keseluruhan usaha ekonomi: formal, informal, ekonomi rakyat, swasta, BUMN, dan koperasi. Keseluruhan itu harus disusun sebagai "usaha bersama" (mutualism) berdasar atas "asas kekeluargaan" (brotherhood). Perkataan "disusun" artinya tidak dibiarkan tersusun sendiri mengikuti kehendak dan selera pasar. "Disusun" artinya didesain, ditata, tidak sekadar diintervensi. Dengan demikian, dalam perekonomian Indonesia, badan usaha swasta dan badan usaha BUMN paham usaha bersama dan asas kekeluargaan harus senantiasa dihidupkan. Kita menjunjung paham bergotong royong dan bekerja sama, tidak berkompetisi saling mematikan. ${ }^{18}$

Dari sini penulis memahamai bahwa yang dimaksud ekonomi humanis dalam makalah ini adalah ekonomi pancasila dimana poin-poin dalam pasal pancasila dan kemudian dijabarkan dalam undang-undang dasar 1945 adalah mengedepankah sebagai pelaku utamanya dalam sistem ekonomi humanis.

\section{SISTEM EKONOMI PASAR BEBAS}

Ekonomi liberal-kapitalistik yang sekarang lebih berkembang dibandingkan dengan sistem ekonomi lainnya, meurut ekonom Sri Edi Swasono sistem ekonomi tersebut digerakkan oleh para homo-economicus, yaitu makhluk ekonomi rakus. Sehingga fenomena sistem ini cenderung hanya mencari kepuasan pribadi atau kelompokserta insting dan perilakunya mencari kepuasan dan keuntungan maksimal. ${ }^{19}$ Mereka menjadi ahli dalam hal meminimumkan biaya dan memaksimalkan perolehan.Mahluk ekonomi rakus ini pada dasarnya apa yang ia pikirkan hanyalah kesenagan pribadi ataupun klompok. Manusia homoeconomicus ini kemudian berinteraksi dengan Globalisasi dunia yang berkembang, dalam taraf tertentu, dapat diidentikkan dengan globalisasi ekonomi. Globalisasi ekonomi ini pada kenyataannya merupakan istilah lain dari ekonomi pasar bebas ataupun kapitalisme global. Kapitalisme global mulai berkembang pesat, segera setelah 'Perang Dingin' yang berakhir tahun 1980-an. Hal-hal tersebut merupakan pemicu utama berkembangnya kapitalisme global atau globalisasi ekonomi yang diawali dengan pertemuan General Agreement on Trade and Tarrif (GATT) di Maraquesh, Maroko, 1993. Robert Heilbroner dalam bukunya 21st Century Capitalisme (1993) menyatakan bahwa dalam diri kapitalisme itu sendiri ada daya gerak atau pembangkit yang selalu bekerja menghasilkan perubahan yang konstan dengan tujuan yang jelas (Heilbroner, 1993: 41). 20

Kapitalisme global sebenarnya merupakan kelanjutan dan penyempurnaan dari kapitalisme klasik yang telah dikritik oleh Karl Marx. Kalau dalam kapitalisme klasik ruang lingkup atau jangkauan kekuasaannya hanya dalam satu negara, maka dalam kapitalisme global dunia seakan tidak mempunyai sekat-sekat kedaulatan lagi. Munculnya berbagai perusahaan multinasional merupakan bentuk nyata kehadiran

\footnotetext{
${ }^{18}$ Sri Edi Swasono, "Koperasi."

${ }^{19}$ Sri Edi Swasono, "Koperasi."

${ }^{20}$ Selu Margaretha Kushendrawati, "Masyarakat Konsumen Sebagai Ciptaan Kapitalisme Global: Fenomena Budaya Dalam Realitas Sosial," Makara, Sosial Humaniora 10
} (2006): 54. 
kapitalisme global di dunia. Ekonomi tidak lagi menyangkut urusan dalam negeri, tetapi sudah berkembang menjadi ekonomi sejagad. Pasar berkembang menjadi pasar bebas yang tidak hanya memperdagangkan barang dan jasa, tetapi juga menyangkut pasar mata uang (valuta) dan pasar modal.

Dengan berkembangnya paham-paham global dan semakin terintegrasinya warga dunia dalam satu desa-global, maka globalisasi ekonomi atau pasar bebas akan semakin dapat terwujud. Pasar bebas ini secara niscaya diyakini akan membuat kemakmuran semakin meningkat dan pada gilirannya akan bermuara pada terciptanya masyarakat liberal yang demokratis. Akan tetapi di sisi lain kita menyaksikan adanya ketimpangan antara negara maju dengan negara miskin. Harus diakui sistem kapitalisme global mutlak membutuhkan adanya negara-negara berkembang untuk dijadikan sapi perahan. Memang tidak dapat dielak, dalam ranah tetentu masalah seperti ini lebih cenderung bersifat subjektif, tergantung pada pengidentifikasian diri pengkritik terhadap kemajuan kapitalisme global. Sebagian pemikir, terutama Francis Fukuyama, melihat bahwa perkembangan dunia tidak dapat dielakkan akan mengarah pada terciptanya masyarakat sejahtera yang sempurna dengan sistem demokrasi liberal dan kapitalisme global sebagai payungnya ${ }^{21}$. Dunia sedang berkembang secara deterministis menuju bentuk final yang ideal, yakni kapitalisme global dan demokrasi liberal. Kedua tatanan tersebut diyakini sebagai akhir dari pencarian manusia sepanjang sejarah untuk menemukan bentuk yang paling sempurna.

Secara umum globalisasi ekonomi menyangkut lalulintas barang dan modal secara internasional. Dalam hal ini kapitalisme global identik dengan pasar bebas, di mana modal dari suatu negara atau dari suatu badan usaha bebas berpindah ke mana saja, ke tempat modal tersebut paling menguntungkan. ${ }^{22}$

Lalulintas modal tersebut tidak berjalan sendirian, tetapi membawa serta pengaruh, kekuasaan yang berifat hegemonis. Pasar bebas merupakan istilah yang bisa mewakili kapitalisme global. Dengan pasar bebas maka kekuasaan negara dalam bidang ekonomi semakin diperkecil, bahkan kalau bisa dihilangkan sama sekali. Pasar diyakini mempunyai mekanisme sendiri untuk mensejahterakan masyarakat, tanpa campurtangan negara. Pasar uang internasional mempunyai pengaruh yang signifikan dalam menata perekonomian suatu negara ${ }^{23}$. Dalam hal ini kapitalisme global mirip dengan sebuah "kerajaan abstrak" yang punya kecenderungan ekspansi kekuasaan, bukan hanya sebatas memperluas wilayah kekuasaan melewati batas-batas teritorial suatu negara, tapi juga menyangkut perluasan cakupan usaha dan pengaruh. Kapitalisme global dewasa ini tidak hanya terbatas pada perdagangan komoditi, tetapi lebih merupakan perdagangan jasa dan keuangan serta saham; yang pada hakikatnya merupakan entitas abstrak ${ }^{24}$.

Maka, globalisasi dapat diidentikkan dengan kapitalisme global yang menuntut perubahan konstan dan tujuan jelas. Dengan adanya kapitalisme global ini maka pasar berkembang menjadi pasar bebas yang tidak hanya menyangkut komoditas dan jasa tetapi juga pasar valuta dan pasar modal. Dalam situasi itu masyarakat terkondisi sebagai masyarakat yang liberal dan demokratis karena kapitalisme global hanya dapat berkembang dalam ranah seperti itu.

Seperti disebutkan di atas, salah satu ciri utama kapitalisme adalah kebebasan individual. Oleh Friedman kebebasan ini dijabarkan menjadi "kebebasan ekonomi" dan

${ }^{21}$ B. Herry-Priyono dan Wibowo, I (ed.). Sesudah Filsafat; Esei-esei untuk Franz MagnisSuseno, Yogyakarta: Penerbit Kanisius. (2006): 136

${ }^{22}$ George Soros, Open Society: Reforming Global Capitalism, New York: Public Affairs ${ }^{\mathrm{TM}}$ (1998): 171-172

${ }^{23}$ George Soros, Open Society: Reforming Global Capitalism: 167-168

${ }^{24}$ George Soros, Open Society: Reforming Global Capitalism. 
"kebebasan politik." Menurutnya, kebebasan ekonomi adalah syarat mutlak kebebasan politik. Argumen Friedman ini sejalan dengan pendapat ekonom-ekonom Austria seperti von Mises, Hayek, dan Simons. Akan tetapi, ia berbeda dengan pendapat ekonom klasik Jeremy Bentham. Menurut Bentham, kausalitasnya justru sebaliknya, kebebasan politik adalah syarat menuju kebebasan ekonomi.

Menurut Friedman dan mazhab Austria, jika kausalitas itu berjalan a la Bentham, produknya adalah kolektivisme. Ketika kebebasan politik tercapai, pemerintah berusaha "mengatur" sistem ekonomi agar dapat mencapai kebebasan ekonomi. Namun, menurut mereka, ini adalah kontradiksi, karena ia akan menjurus kepada pemusatan kekuatan, secara sadar ataupun tidak. Akhirnya, yang terjadi adalah ekploitasi, dan lantas menuju, apa yang disebut Hayek sebagai "road to serfdom" jalan (kembali) ke penindasan. ${ }^{25}$ Untuk mendukung argumennya, Friedman menyebutkan contoh di mana sistem ekonomi kapitalis berkembang dalam sistem pemerintahan yang non-demoratis: fasis Italia, Spanyol, Jerman, Jepang, dan Rusia sebelum PD II. Lebih tegas lagi, Friedman mengatakan, hanya ada dua pilihan dalam mengorganisir aktivitas ekonomi: sistem totaliter yang koersif atau sistem pasar yang sukarela. Yang terakhir ini dicirikan oleh "private enterprises" dan "strictly voluntary exchanges." 26

"Sayang"-nya, banyak ekonom yang menyalahartikan kalimat Friedman di atas. Beberapa ekonom pasar radikal kanan bahkan mengharamkan sama sekali peran negara dalam perekonomian. ${ }^{27}$ Padahal, Friedman telah menyatakan bahwa eksistensi pasar bebas bukan berarti peran pemerintah sama sekali ditiadakan. Pemerintah tetap dibutuhkan, namun dalam wilayah yang sangat dibatasi. Menurut Friedman, pemerintah diperlukan untuk menetapkan "rules of the game" dan untuk menjamin pelaksanaan aturan-aturan tersebut. Pasar yang efisien dengan sendirinya akan mengurangi peran- peran pemerintah yang tidak perlu.

Eko Prasetyo ${ }^{28}$ menjelaskan bahwa Adam Smith adalah peletak dasar pemikiran kapitalisme yang menjelaskan bekerjanya mekanisme hukum pasar atas dasar dorongan kepentingan-kepentingan pribadi karena kompetisi dan kekuatan individualisme dalam menciptakan keteraturan ekonomi. ${ }^{29}$ Melaluinya, kapitalisme melakukan klasifikasi antara nilai guna dengan nilai tukar yang ada pada setiap komoditi. Ukuran riil dari nilai tukar komoditi, harus dilihat dari kondisi pertukaran, dimana 'ukuran riil' dari nilai komoditi adalah kuantitas dari kerja yang berada dalam barang-barang lain yang dapat dipertukarkan di pasar. Tokoh berikutnya yang penting adalah David Ricardo, yang melakukan kritik terhadap Adam Smith, terutama yang berkaitan dengan nilai komoditi. Menurutnya, nilai komoditi terdapat pada kerja manusia berikut bahan-bahan mentah dan alat-alat kerja. Ricardo menemukan bahwa komoditi yang dijual pada harganya, kira-kira akan setara dengan jumlah kerja yang diperlukan untuk memproduksinnya. Asumsinya satu-satunya nilai tukar, berawal dari jumlah kerja yang digunakan untuk memproduksi, Karenanya dari Ricardo-lah

${ }^{25}$ Friedrich A. Hayek, Ancaman Kolektivisme, 48.

${ }^{26}$ Friedrich A. Hayek, Ancaman Kolektivisme, 49.

${ }^{27}$ Kelompok ini salah satunya dikenal sebagai "anarcho-liberal". Salah satu tokohnya (atau sumber yang suka mereka pakai) adalah David Friedman, anak Milton Friedman.

${ }^{28}$ Eko Prasetyo, "Kapitalisme dan Neo-Liberalisme: Sebuah Tinjauan Singkat," dalam Ekonomi Politik Journal Al-Manär, Edisi I, (2004), 2.

${ }^{29}$ Kalimat yang populer dari Adam Smith "Bukanlah dari kemurahan hati tukang daging, tukang bir atau tukang roti', kita mengharapkan mendapat makanan; melainkan dari penghargaan mereka atas kepentingan diri mereka masing-masing. Kita camkan dalam diri kita, bahwa bukanlah dari rasa kemanusiaan, melainkan dan rasa cinta terhadap diri-sendiri; dan tak akan kita berbicara pada mereka mengenai kebutuhan-kebutuhan kita bersama, melainkan atas dasar laba yang bisa mereka raih. Lihat Bonnie Setiawan, Peralihan Kapitalisme Di Dunia Ketiga, (Yogyakarta: Insist Press, 1999). 
sifat parasit dari seluruh pendapatan yang tidak diperoleh dari kerja terbongkar, sebab darinya, kelak akan ditemukan apa yang dinamai dengan nilai lebih dan kerja lebih.

Kedua ilmuwan ini menjadi peletak dasar bagi ideologi kapitalisme awal dan mereka hidup pada masa transisi dari ekonomi subsistem menuju pada sistem ekonomi pasar, yang mengandalkan pada laba. Sejumlah ilmuwan kemudian memberikan pendasaran historis tentang masa peralihan ke kapitalisme ini dengan ditandai oleh sejumlah indikator: pertama meningkatnya output pertanian yang bersamaan dengan pemisahan petani-petani dari tanahnya, kedua pertumbuhan produksi komoditi dan pembagian kerja, ketiga akumulasi modal oleh pedagang dan petani kaya. Paul Baran menyatakan bahwa kapitalisme terbentuk ketika terjadi akumulasi modal dalam bentuk modal dagang yang kemudian menjadi dasar ekspansi Eropa dimana negara memberikan dukungan terhadap kompetisi ${ }^{30}$ Pasca Perang Dunia II ini telah membawa upaya beberapa negara, terutama Amerika, untuk memimpin proses rekonstruksi.

Itu sebabnya kehadiran IMF menjadi diperlukan terutama ketika banyak negara tidak mampu membayar hutangnya kembali. Semula Meksiko yang gagal membayar hutangnya yang jatuh tempo pada tahun 1982. IMF, pada saat Meksiko mengalami masalah, diperlukan untuk membantu menyelamatkan neraca pembayaran dan mengatur perundingan restrukturisasi utang dengan kalangan Perbankan International. Perannya menjadi kian penting saat Asia memasuki krisis terberatnya pada dekade 1997 dimana IMF mencoba ikut memecahkan. Salah satu program IMF yang populer dinamakan dengan SAP (Structural Adjusment Program) yang didasarkan atas keyakinan bahwa sektor swasta lebih efektif, dinamis dan bereaksi lebih baik terhadap ekonomi pasar daripada sektor pemerintah. Karenanya IMF selalu mendorong setiap negara untuk berintegrasi dalam pasar dunia melalui beberapa kebijakan, di antaranya: pertama menurunkan nilai tukar mata uangnya agar lebih kompetitif, kedua mengurangi hambatan-hambatan perdagangan sehingga mendorong industri lokal lebih kompetitif dalam menghadapi produk impor yang lebih murah, ketiga memberikan insentif ekspor seperti keringanan pajak dan subsidi keuangan, keempat merangsang investasi asing dengan menciptakan wilayah perdagangan bebas atau memberikan pembebasan pajak. Di samping sejumlah program ini juga ada sejumlah bantuan yang berada di bawah program-program IMF yang tetap konsisten dengan paradigma utamanya, yakni mencebur dalam mekanisme pasar bebas.

Marx meramalkan bahwa kapitalisme akan hancur melalui revolusi proletar. Revolusi ini dipicu oleh frustrasi kelas pekerja akibat ekploitasi oleh kelas kapitalis. Mereka (para pekerja) diperlakukan hanya sebagai komoditas (commodity fetishism). Kapitalis menghisap rente yang berasal dari selisih antara upah pekerja dengan harga jual barang (surplus value). Hancurnya kapitalisme akan melahirkan masyarakat sosialis, dimana kepentingan bersama selalu diletakkan di atas kepentingan pribadi, dan "from each according to his ability to each according to his needs." Tahap matang dari sosialisme adalah komunisme, di mana masyarakat tidak lagi mengenal kelas. Hak pribadi lebur menjadi hak komunal. Semua sama, dan pemerintah mengatur segalanya. Jadi, sosialisme/komunisme, menurut Marx, adalah konsekuensi logis dari kapitalisme. Ternyata, sampai saat ini diktum Marx tidak terbukti. Yang terjadi justru sebaliknya: kapitalisme semakin berkembang. ${ }^{31}$

Ada satu faktor lain selain sosialisme dan kapitalisme yang selalu menyertai, demokrasi. Triumvirat ini pertama kali dipopulerkan oleh Schumpeter. Sama dengan Marx, Schumpeter juga meramalkan keberhasilan sosialisme dan kejatuhan kapitalisme. Lebih jauh, Schumpeter berargumen bahwa demokrasi bisa tumbuh lebih

${ }^{30}$ Lihat Bjorn Hettne, Teori Pembangunan dan Tiga Dunia (Jakarta: Gramedia, 2001).

${ }^{31}$ Anonym, "Kapitalisme," dalam www.pk-sejahtera.us/kastra/pdfs/kapitalisme.pdf, diakses tanggal 26 Maret 2013. 
subur dalam masyarakat sosialisme ketimbang masyarakat kapitalisme. Sekalipun begitu, Schumpeter mengatakan bahwa kapitalisme dan demokrasi mempunyai hubungan mutual. Kejatuhan kapitalisme lebih merupakan proses alami (creative destruction) menuju sosialisme, di mana kemudian demokrasi lebih berkembang lagi. Ketika Schumpeter menulis buku itu, kondisi ekonomi-politik di negara komunis, seperti Uni Soviet sedang jelek-jeleknya dan sungguh jauh dari demokrasi. Tapi Schumpeter mengatakan bahwa kondisi Uni Soviet tidak boleh dijadikan patokan akan masa depan sosialisme, karena banyak hal yang dilakukan para czar Rusia di Uni Soviet tidak konsisten dengan prinsip-prinsip sosialisme dan komunisme. Juga, seperti ramalan Marx, tesis Schumpeter belum terbukti. Yang terjadi - paling tidak seperti yang diklaim oleh banyak penganut kapitalisme - demokrasi justru identik dengan kapitalisme. ${ }^{32}$

"Identik" tentu bukan istilah yang memuaskan. Sepintas lalu, kita paham bahwa kapitalisme tidak sama dengan demokrasi. "Identik" di sini seharusnya bukan tanda sama dengan, tapi harus dijelaskan hubungan sebab-akibatnya. Robert Dahl menjadikan tema ini sebagai fokus dalam bukunya, "Democracy and Its Critics" (1989). Manurut Dahl, kapitalisme adalah syarat perlu (necessary condition) dari demokrasi, sekalipun bukan syarat cukup (sufficent condition). Hal yang sama dikatakan oleh Peter Berger dalam "Capitalist Revolution" (1986)..$^{33}$

Kapitalisme belakangan ini mulai menunjukkan tanda-tanda keredupannya. Semenjak sistem kapitalisme mendominasi sistem perekonomian dunia, hampir semua negara pernah mengalami krisis yang menggoyahkan stabilitas. Krisis demi krisis ekonomi terus berulang dalam sejarah. Tercatat sejak tahun 1923, tahun 1930, tahun 1940, tahun 1970, tahun 1980, tahun 1990, dan dan tahun 1998-2001, bahkan pada tahun 2008 krisis semakin mengkhawatirkan dengan munculnya krisis finansial di Amerika Serikat, yang memberikan efek domino ke berbagai negara di penjuru dunia. ${ }^{34}$ Roy Davies dan Glyn Davies menjelaskan dengan jelas kronologi krisis ekonomi dunia secara menyeluruh. Sepanjang Abad ke-20 telah terjadi lebih 20 kali krisis besar yang melanda banyak negara. Ini berarti, rata-rata setiap 5 tahun terjadi krisis keuangan hebat yang mengakibatkan penderitaan bagi jutaan umat manusia. ${ }^{35}$

\section{KESIMPULAN}

Sistem ekonomi humanis dalam hal konsep diatas milik kesamaan dengan nilainilai Islam, bahakan ekonomi humanis ini mengedepnkan kebesamaan, saling tolong menolong dan memiliki dimensi spritualitas yang tinggi, dan ini berbeda jauh dengan ekonomi pasar bebas yang dikembangkan oleh sitem ekonomi kapitalis global. Sitem ekonomi pasar bebas ini cenderung manusia dijadikan sebagai objek, sehingga terjadi

${ }^{32}$ Anonym, "Kapitalisme," dalam www.pk-sejahtera.us/kastra/pdfs/kapitalisme.pdf, diakses tanggal 26 Maret 2013.

${ }^{33}$ Anonym, "Kapitalisme," dalam www.pk-sejahtera.us/kastra/pdfs/kapitalisme.pdf, diakses tanggal 26 Maret 2013.

${ }^{34}$ Situasi ini dipicu oleh terjadinya kredit macet di sektor properti (subprime mortgage) sehingga menyebabkan industri subprime mortgage skala besar seperti American Home Mortgage Investment Corporation (AHMI), Mortgage Guaranty Insurance Corporation (MGIC), dan New Cen tury Financial Corporation (NCFC), jatuh bangkrut. Para investor kehilangan biliyunan dollar untuk mencegah agar aset-aset subprime mortgage tidak lenyap. Tindakan ini kemudian memicu terjadinya huru-hara di pasar finansial global. Lebih lanjut baca Coen Husain Pontoh (2007), "Efek Domino Krisis Properti di AS", dikutip dari http://coenpontoh.wordpress.com/2007/09/19/efek-domino-krisis- properti-di-as/ diakses 25 Maret 2013.

${ }^{35}$ Roy Davies and Glyn Davies, The History of Money From Ancient Time of Present Day (New York: Oxford University Press, 1996), 13. 
kesenjangan yang sangat jauh anatar masyarakt dengan para konglomerat, dan ini cir khas dariapada ekonomi pasar bebas. Namun disatu sisi ekonomi humanis memang mengadopsi beberapa sistem kapitalis, seperti halnya kepemilikan induvidual dan juga mengadopsi sebagaian ekonomi sosialisme dalam hal kebersamaannya.

\section{DAFTAR PUSTAKA}

Abbas, Tarmizi, and Win Konadi Manan. "Keterkaitan antara Demokrasi Politik, Demokrasi Ekonomi dan Sistem Ekonomi Kerakyatan." Mimbar: Jurnal Sosial dan Pembangunan 21.3 (2005).

Adi Sasono, Didin Hafiduddin dan AM. Saepuddin dkk membagi tiga paradigma system ekonomi dunia. lihat Adi Sasono dkk, Solusi Islam Atas Problematika Umat: Ekonomi, Pendidikan, dan Dakwah (Jakarta: GIP, 1998)

Anonym, "Kapitalisme," dalam www.pksejahtera.us/kastra/pdfs/kapitalisme.pdf, diakses tanggal 26 Maret 2013.

Anwar Abbas, Bung Hatta dan Ekonomi Islam: Menangkap Makna Maqāshid al-Syarīah (Jakarta: Kompas Media Nusantara, 2010).

B. Herry-Priyono dan Wibowo, I (ed.). Sesudah Filsafat; Esei-esei untuk Franz Magnis-Suseno, Yogyakarta: Penerbit Kanisius. (2006).

Bonnie Setiawan, Peralihan Kapitalisme Di Dunia Ketiga, (Yogyakarta: Insist Press, 1999).

Eko Prasetyo, "Kapitalisme dan Neo-Liberalisme: Sebuah Tinjauan Singkat," dalam Ekonomi Politik Journal Al-Manär, Edisi I, (2004).

George Soros, Open Society: Reforming Global Capitalism, New York: Public Affairs $^{\text {TM }}$ (1998).

Gidden, Anthony, Kapitalisme dan Teori Sosial Modern, Suatu Analisis terhadap Karya Tulis Mark, Durkheim dan Max Weber (Jakarta: UI- Press, 1986);

Giustiniani, V. R. (1985). Homo, humanus, and the meanings of'humanism'. Journal of the History of Ideas, 167-195. Baca juga INDONESIA, P. R., \& Indonesia, P. R. (1984). Undang Undang No. 5 Tahun 1984 Tentang: Perindustrian.

Ilham Firmansyah, "Konsep Ekonomi Pancasila Dan Ekonomi Islam (Analisis Pemikiran Ekonomi Sri-Edi Swasono)."

Ismail, Indriaty, dan Mohd Zuhaili Kamal Basir. "Karl Marx dan Konsep Perjuangan Kelas Sosial." International Journal of Islamic Thought 1 (2012).

Kuswanjono, Arqom. "Pluralisme Pancasila." Jurnal Filsafat 16.1 (2016): 77-93.

Lihat Bjorn Hettne, Teori Pembangunan dan Tiga Dunia (Jakarta: Gramedia, 2001).

Marx, K., Capital. Jil 1. Moscow: Progress ublisher, (1959)

Mustansyir, R. (1995). Bhinneka Tunggal Ika, Dalam perspektif filsafat analitik. Jurnal Filsafat, (1995).

NingrumNatasya Sirait, "Menjual Rugi (Predatory Pricing) Dalam Hukum Persaingan dan pengaturannya dalam undang-undang no 5/1999 dalam jurnal hukum bisnis vo. 1, No. 23. 2004.

Poespowardojo, Soerjanto. "Filsafat Pancasila (Sebuah Pendekatan Sosio Budaya) Gramedia." (1989).

Pranarka, A. M. W. (1985). Sejarah pemikiran tentang Pancasila. Yayasan Proklamasi, Centre for Strategic and International Studies.

Roy Davies and Glyn Davies, The History of Money From Ancient Time of Present Day (New York: Oxford University Press, 1996), 13. 
Selu Margaretha Kushendrawati, "Masyarakat Konsumen Sebagai Ciptaan Kapitalisme Global: Fenomena Budaya Dalam Realitas Sosial," Makara, Sosial Humaniora 10 (2006).

Soesastro, M. Hadi. "The political economy of deregulation in Indonesia." Asian Survey 29.9 (1989): 853-869; baca Doyle, Michael W. "Liberalism and world politics." American political science review 80.4 (1986).

Sri Edi Swasono, "Koperasi: Koperasi dan Ekonomi Humanistik," diakses 30 November 2017, / koperasi-dan-ekonomi-humanistik.html.

Stiglitz. Joseph. Freefall: America, Free Market and The Sinking of Global Economy (New York: Norton Company, 2009).

Suroso. Perekonomian Indonesia. Jakarta: PT. Gramedia Pustaka Utama, 1994.

Tarigan, Azhari Akmal. "Peraktek Monopoli Dan Persaingan USAha Tidak Sehat Dalam Perspektif Hukum Ekonomi Dan Hukum Islam." JURNAL MERCATORIA 9.1 (2017).

Winardi, Kapitalisme Versus Sosialisme (Bandung: Remadja Karya, 1986).

Zubadi, Hamron. "Perlunya Pengenalan Pendidikan Ekonomi Islam dengan Sistem Ekonomi yang Lain Sejak Dini." Jurnal Fakultas Ekonomi 1.3 (2013). 